\title{
Modeling Constraints for the On-Site Assembly Process of Prefabrication Housing Production: A Social Network Analysis
}

\author{
Pan Gong ${ }^{1, *}$, Yue Teng ${ }^{2, *\left(\mathbb{C},{\mathrm{Xiao} \mathrm{Li}^{3}}^{3} \text { and Lizi Luo }\right.}{ }^{3}$ (i) \\ 1 School of Construction Management and Real Estate, Chongqing University, Chongqing 400044, China \\ 2 Department of Civil Engineering, the University of Hong Kong, Hong Kong, China \\ 3 Department of Building and Real Estate, the Hong Kong Polytechnic University, Hong Kong, China; \\ shell.x.li@connect.polyu.hk (X.L.); lizi.luo@connect.polyu.hk (L.L.) \\ * Correspondence: 20170313088t@cqu.edu.cn (P.G.); tengyue@hku.hk (Y.T.)
}

Received: 19 January 2019; Accepted: 26 February 2019; Published: 6 March 2019

\begin{abstract}
Although prefabrication housing production (PHP) has been widely advocated with advantages like ensured good quality and secured workplaces, its poor interoperability and fragmentation still causes various constraints, limiting the progress of projects. This paper aims to model the constraints and their relationships in task executions of different trades during the on-site assembly process of PHP. It was conducted through a typical PHP case study in Hong Kong to identify the critical trade associated constraints and their links during the on-site assembly process. Original data were collected by semi-structured interview, Delphi survey and questionnaire with representative professionals from the case. Social Network Analysis (SNA) was used to model the constraints and their interrelationships. The results indicated that seven trade-associated constraints were worth more attention. Three significant challenges were determined, indicating that the on-site team should focus on the availability of labor resources, optimal installation planning and effectiveness of communication mechanism. Smart work packaging (SWP)-enabled system for achieving automatic constraint identification and dynamic constraint relationship mapping under different constraint scenarios was suggested. This paper offers practical insights for scholars to conduct a trade-associated constraint identification study in the network manner and is expected to benefit practitioners on using the results for decision-making.
\end{abstract}

Keywords: prefabrication housing production (PHP); constraint modeling; social network analysis (SNA); on-site assembly process

\section{Introduction}

Prefabrication housing production (PHP) is an innovative solution where the material, component, module and unit are manufactured efficiently at one location and then be converged at the site for installation [1]. It has strong potential to improve the industry-wide performance such as ensured good quality [2], secured workplaces [3], reduced construction time and waste [4] due to working in a controlled environment. As a high-density city, Hong Kong has widely advocated the use of PHP to the development of all the public rental housing (PRH), in order to mitigate the unbalanced housing supply and demand. The six-day cycle has been continually adopted in the assembly process of PHP [5]. Each typical floor is completed within six days; otherwise, the overall schedule performance will be influenced. Nevertheless, the constraints (e.g., limited space and buffers) among different trades in the assembly process impose significant pressure on the construction progress. As a result, the pathological schedule delay frequently occurs, resulting in the difficulties to meet the high housing 
demand. According to the Hong Kong Housing Authority (HKHA), about 153,300 general applications are on the waiting lists of PRH at the end of March 2018 and the average waiting time is 5.1 years. Previous studies have been conducted to identify the risks within the supply chain of PHP, for achieving the phase schedule control from a macro aspect [1]. However, the status of prefabricated products changes over time during the on-site assembly process, daily detailed schedule control and planning to issue executable work plans are thus vital and urgent. Therefore, this paper aims to model the constraints and their interrelationships in task executions of different trades during the on-site assembly process of PHP, in order to control the critical constraints. Constraint modeling is the first but critical functional strategy of constraint management, which allows crews to have a thorough understanding of interconnections among tasks or activities. To be more specific, three objectives are achieved: (1) To identify the constraints and their relations in and among different trades during the on-site assembly process of PHP; (2) To explore the critical constraints and the interrelationships that significantly affect the schedule of PHP; (3) To explore corresponding strategies for addressing the challenges encountered in the constraint modelling of PHP. The findings are supposed to help scholars conduct a trade-associated constraint identification study in the network manner and benefit practitioners by making them aware of the schedule controlling for further decision-making.

\section{Research Background}

\subsection{Prefabrication Housing Production (PHP) in Hong Kong}

PHP is commonly referred to as off-site construction, precast construction, modular construction, industrialized building system and pre-assembly construction [6]. The PHP in Hong Kong uses the principles of industrialization in the multi-stages of construction projects, including design, manufacturing, logistics and on-site assembly. The product-oriented on-site assembly process of PHP is presented in Figure 1, which shows the trade (human resources) involvements in the different status of prefabricated products. First, the expeditor delivers the daily order to the manufacturing factory. When the prefabricated products (1) are fabricated and prepared well, they are delivered to the construction site with the on-site quality check by the quality inspector. Second, the prefabricated products (2) are arranged by the buffer foreman before being lifted by tower crane. The tower crane will be maintained regularly by tower foreman to guarantee the safe operations of crane. During the on-site assembly process, the crane banksman and the prefabricated products installer are vital to provide accurate information in the lifting and placing process. General workers will help to handle some temporary work on site. Third, the assembled prefabricated products (3) will then be checked by the quality inspector again. The unqualified products will be returned to the factory for rework. The site superintendent and the safety supervisor should conduct the general planning and control and supervise safety issues on site.

Although several benefits of PHP have been demonstrated, the schedule delay still happens [5]. The scheduling problem is amplified in Hong Kong since the manufacturing work of PHP has been completely shifted offshore, resulting in various uncertainties and constraints. Some studies have investigated the stakeholder-associated uncertainties within the supply chain of PHP $[1,7]$. They concluded that the schedule delay was mainly caused by the design information gap between designers and manufacturers, the low interoperability between different enterprises and the delivery delay of prefabricated products. To improve the visibility and traceability of prefabricated products, the internet of things (IoT)-enabled Building Information Modeling (BIM) platform was suggested for achieving just-in-time (JIT) coordination [8-10]. These studies are helpful to mitigate the uncertainties within phase schedule. However, there are still massive constraints have not been improved in a more detailed schedule. For example, the detailed tasks still beset some missing or incomplete prerequisites including design (drawings and models), prefabricated products, space, buffer, labor, equipment, permits, specifications, prerequisite work, which prevent the reliability of PHP workflow [11]. 


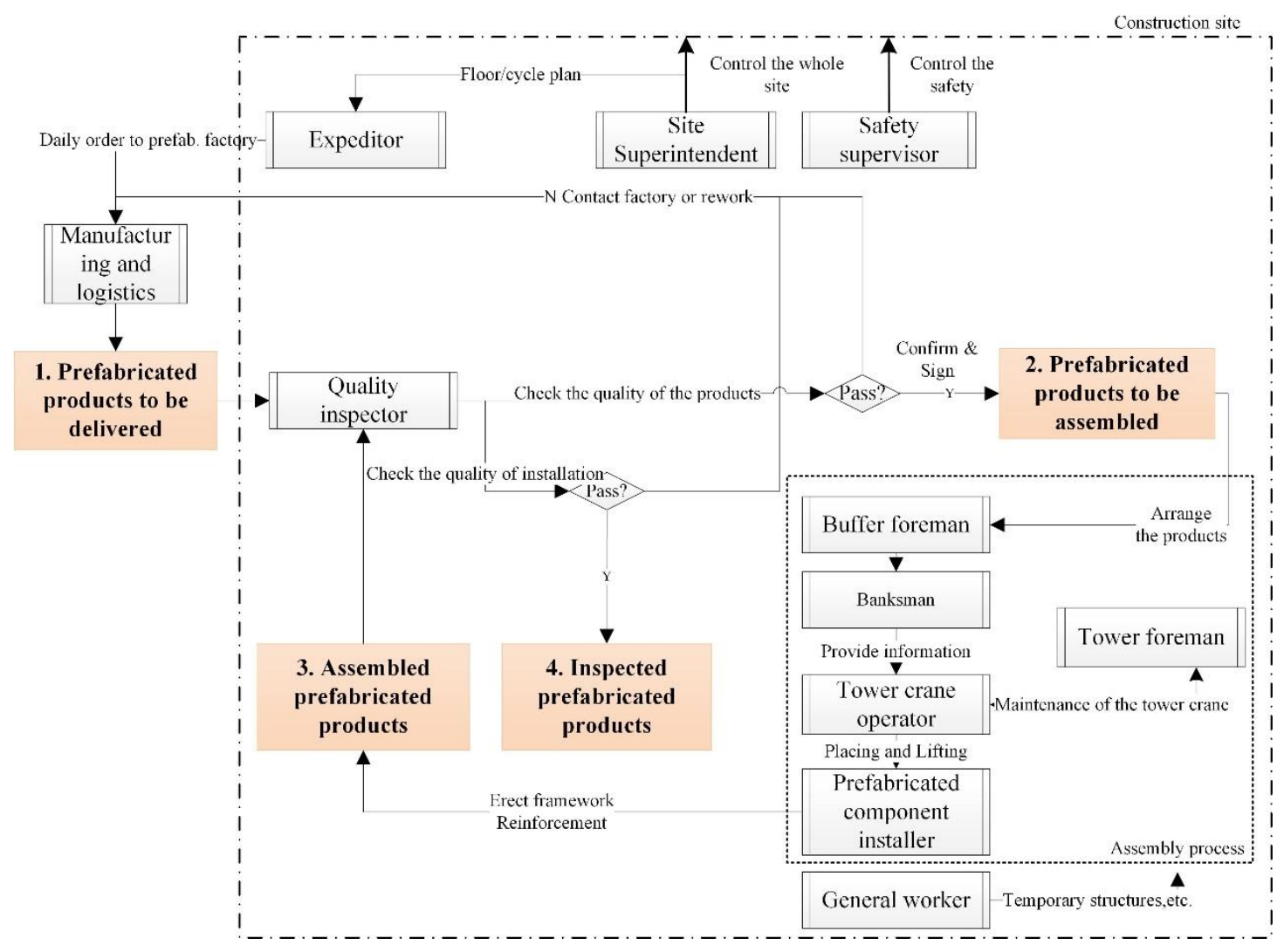

Figure 1. On-site assembly process of prefabrication housing production (PHP).

\subsection{Constraint Identification in the Assembly Process of PHP}

Constraints in a construction process are defined as any condition, such as technical sequencing, temporal/spatial limitations and safety/quality concerns, which restrain work plans assigned to construction crews being successfully executed [12]. Research undertaken previously have identified a series of bottlenecks that affect the whole processes of PHP. For example, Blismas, Pendlebury [13] identified 20 constraints related to PHP, showing that constraints existing in the process, value, supply chain and knowledge were significant. Gibb and Isack [14] examined the limiting factors in terms of cost, time and quality. Zhang, Lee [15] proposed that the most significant hindrances for PHP were the inflexible design change, the lack of storage space, long lead-in and design time and high cost. Leu and Hwang [16] pointed out that limited resources (e.g., cranes and skilled labor) should be addressed. Blackmon, Saxena [12] examined 17 constraints related to field operations, showing that effective management of these constraints would be a key element to ensure a constraint-free work plan. In addition, previous studies usually investigated constraints and trades as two independent systems and seldom considered the links between them. Table 1 shows the constraints influencing the on-site assembly process of PHP identified by previous studies. To avoid any missed information and to explore the situations specifically to the PHP of Hong Kong, these constraints identified are used as references for further validation through semi-structured interviews. 
Table 1. Constraints identified by previous studies in on-site assembly process of PHP.

\begin{tabular}{|c|c|c|c|c|c|c|c|c|c|c|}
\hline \multirow{2}{*}{ Constraints } & \multirow{2}{*}{ Explanation } & \multicolumn{9}{|c|}{ Reference } \\
\hline & & [1] & [12] & [13] & [15] & [17] & [18] & [19] & [20] & [14] \\
\hline Incomplete shop drawings and BIM models & Shop drawings and BIM models can improve the constructability & $\sqrt{ }$ & $\sqrt{ }$ & $\sqrt{ }$ & & $\sqrt{ }$ & & & & \\
\hline Incomplete specifications & $\begin{array}{l}\text { Specifications are detailed descriptions of the materials, } \\
\text { workmanship and standard. }\end{array}$ & $\sqrt{ }$ & $\sqrt{ }$ & & & & & & & \\
\hline Lack of permits & The official approvals issued to the construction activities. & & & $\sqrt{ }$ & & $\sqrt{ }$ & $\sqrt{ }$ & & & $\sqrt{ }$ \\
\hline Unavailable and unassigned labour resources & The skilled workers are recruited and ready for task executions & $\sqrt{ }$ & $\sqrt{ }$ & $\sqrt{ }$ & $\sqrt{ }$ & $\sqrt{ }$ & $\sqrt{ }$ & & $\sqrt{ }$ & $\sqrt{ }$ \\
\hline Bad weather conditions & $\begin{array}{l}\text { Adverse weather causes the delay and shutdown, e.g., } \\
\text { heat-stress, typhoon. }\end{array}$ & $\sqrt{ }$ & & & & & & & & $\sqrt{ }$ \\
\hline $\begin{array}{l}\text { Unavailable production and transportation } \\
\text { schedule }\end{array}$ & The just-in-time deliveries of products can not be guaranteed. & & & & $\sqrt{ }$ & $\sqrt{ }$ & & & $\sqrt{ }$ & $\sqrt{ }$ \\
\hline Bad conditions of transportation vehicle & $\begin{array}{l}\text { The height and weight limit on the road for the vehicle and } \\
\text { traffic congestion. }\end{array}$ & $\sqrt{ }$ & & $\sqrt{ }$ & $\sqrt{ }$ & & $\sqrt{ }$ & & & $\sqrt{ }$ \\
\hline Unavailable quality control hold-points & It determines where to conduct quality inspection and testing. & & $\sqrt{ }$ & & & & & $\sqrt{ }$ & & $\sqrt{ }$ \\
\hline Lack of inspection and testing instructions & It determines how to conduct quality inspection and testing. & & & & $\sqrt{ }$ & $\sqrt{ }$ & & & & \\
\hline $\begin{array}{l}\text { Incomplete identification of installation } \\
\text { products }\end{array}$ & To recognize the prefabricated products in a fast manner. & $\sqrt{ }$ & $\sqrt{ }$ & & & & & & & \\
\hline Unavailable equipment, devices and tools & They are necessary for workers to execute tasks & $\sqrt{ }$ & $\sqrt{ }$ & $\sqrt{ }$ & & $\sqrt{ }$ & & & & \\
\hline Lack of crane maintenance plan & It determines the efficient operation of the tower crane & $\sqrt{ }$ & & & & & & & & \\
\hline Lack of communication mechanism & $\begin{array}{l}\text { It is the key factor for transferring products between different } \\
\text { trades. }\end{array}$ & $\sqrt{ }$ & & & & $\sqrt{ }$ & & & & \\
\hline Inadequate buffer space & It limits the storage capacity for prefabricated products & & $\sqrt{ }$ & $\sqrt{ }$ & & & & $\sqrt{ }$ & & \\
\hline Lack of optimal buffer layout & It affects both the storage capacity and the installation sequence & $\sqrt{ }$ & & $\sqrt{ }$ & $\sqrt{ }$ & & & $\sqrt{ }$ & & \\
\hline Lack of optimal installation sequence & The inadequate installation sequence leads to the rework. & $\sqrt{ }$ & & & & & & $\sqrt{ }$ & $\sqrt{ }$ & \\
\hline Inadequate workface/work space & It prevents enough space for workers from executing tasks & $\sqrt{ }$ & $\sqrt{ }$ & $\sqrt{ }$ & $\sqrt{ }$ & & & & & \\
\hline Unavailable installation instructions & $\begin{array}{l}\text { The instructions can guide the workers to install the } \\
\text { prefabricated products properly. }\end{array}$ & & $\sqrt{ }$ & & $\sqrt{ }$ & $\sqrt{ }$ & & $\sqrt{ }$ & & \\
\hline Unavailable temporary structures & It can reduce the workface and lead to potential safety hazards. & & $\sqrt{ }$ & & & & & $\sqrt{ }$ & & \\
\hline $\begin{array}{l}\text { Inadequate safety training \& hazards } \\
\text { identification }\end{array}$ & $\begin{array}{l}\text { It reduces the ability of hazards prevention, identification and } \\
\text { alerting. }\end{array}$ & $\sqrt{ }$ & $\sqrt{ }$ & & $\sqrt{ }$ & $\sqrt{ }$ & & & & $\sqrt{ }$ \\
\hline $\begin{array}{l}\text { Incomplete special personal protection } \\
\text { equipment (PPE) instructions }\end{array}$ & $\begin{array}{l}\text { PPE refers to protective clothing, helmets, goggles and so on, } \\
\text { preventing workers from dangers. }\end{array}$ & & $\sqrt{ }$ & & & & & & & \\
\hline
\end{tabular}




\section{Methodology}

Three distinct steps are carried out to meet the objectives of the paper: identification of the trade associated constraints, determination of constraint links, network visualization and quantitation. Figure 2 shows the methodology adopted in this paper.
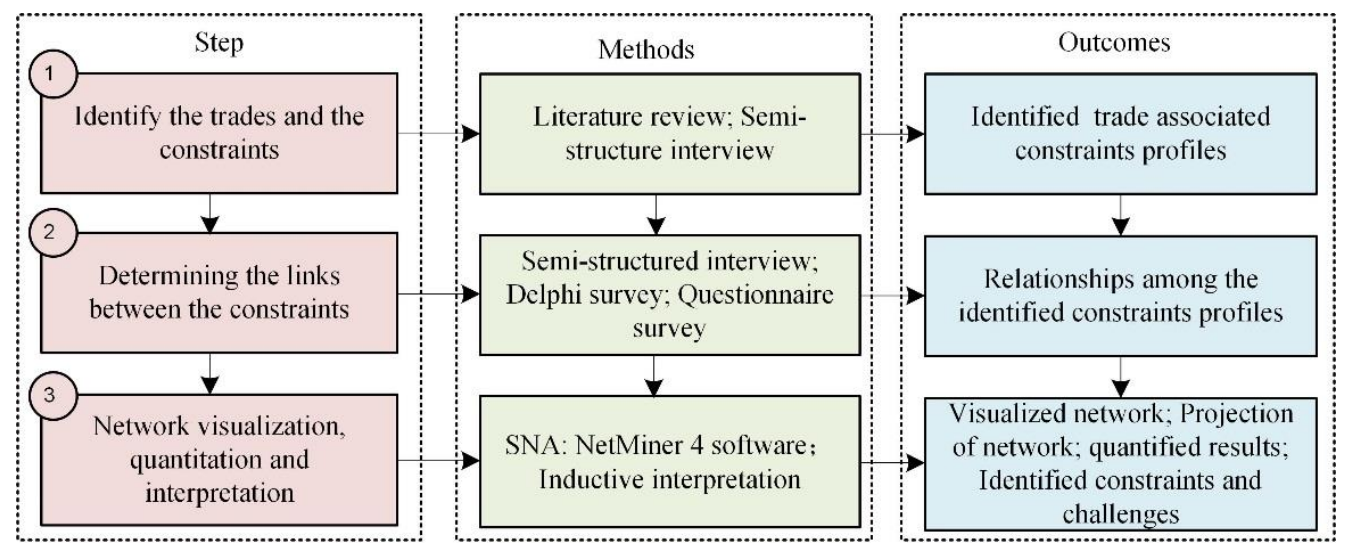

Figure 2. Framework of methodology.

\subsection{Identification of the Trade Associated Constraints}

The first step is to identify the trades and their constraints during the on-site assembly process of PHP. Literature review and semi-structured interview were adopted as the input data resources. The chain-referral sampling method was adopted in this step. Three representatives from the contractors of a typical PHP in Hong Kong were selected as they had direct involvement in the assembly process of the project, and they were all above senior management level. A tentative trade list for assembling the precast component (which was compiled based on literature review) was used as a reference. The Construction Industry Council (CIC) in Hong Kong has listed 139 building construction trades and those related to the on-site assembly process of prefabrication were selected in the tentative trade list. These three nominated parties were invited to select the closely-related trades and their associated constraints in the lists and to locate any impacted groups which were still absent. For example, one of the interviewees pointed out that "The work of a tower crane operator is often affected the lack of blind zone operation procedure/instruction, the unavailable lifting and placing location and the lack of communication mechanism. These constraints will have significant influences on the schedule control of the PHP projects". After a series of interviews, 10 trades (Ti) were finally confirmed, namely, (1) site superintendent, (2) expeditor, (3) quality inspector, (4) tower crane operator, (5) tower foreman, (6) crane banksman, (7) buffer foreman, (8) prefabricated components Installer, (9) general laborer, (10) safety supervisor. Apart from 21 constraints identified by literature review in Table 1, other 10 constraints (C7, C10, C13, C14, C15, C16, C19, C24, C25, C30) were examined through the semi-structured interviews (Table 2). The transcripts of the three interviews were sent again to the representatives of the identified 10 trades for feedbacks. The outcomes of the first step are identified trade-associated constraints profiles. Therefore, a total of 31 constraints were identified, with 10 respective trades generating 65 nodes. These constraints are grouped into two broad categories (information and physical) and several subcategories according to their characteristics, namely quality, schedule, safety, resource, prerequisite work and environment. These nodes were coded as $\mathrm{TiC} j$, where $i$ represents a specific trade and $j$ indicates the related constraint factor. 
Table 2. Identified trades and associated constraints.

\begin{tabular}{|c|c|c|c|}
\hline ID & Trades & Constraints & Category \\
\hline $\begin{array}{l}\mathrm{T} 1 \mathrm{C} 1 \\
\mathrm{~T} 8 \mathrm{C} 1\end{array}$ & $\begin{array}{l}\text { T1: Site superintendent } \\
\text { T8: Prefabricated products Installer }\end{array}$ & $\begin{array}{l}\text { C1: Incomplete shop drawings and BIM } \\
\text { models }\end{array}$ & Informational quality \\
\hline $\begin{array}{l}\text { T1C2 } \\
\text { T3C2 } \\
\text { T5C2 } \\
\text { T8C2 }\end{array}$ & $\begin{array}{l}\text { T1: Site superintendent } \\
\text { T3: Quality inspector } \\
\text { T5: Tower foreman } \\
\text { T8: Prefabricated products Installer }\end{array}$ & C2: Incomplete specifications & Informational quality \\
\hline $\mathrm{T} 1 \mathrm{C} 3$ & T1: Site superintendent & C3: Lack of permits & Informational quality \\
\hline $\begin{array}{l}\text { T1C4 } \\
\text { T5C4 }\end{array}$ & $\begin{array}{l}\text { T1: Site superintendent } \\
\text { T5: Tower foreman }\end{array}$ & $\begin{array}{l}\text { C4: Unavailable and unassigned labor } \\
\text { resources }\end{array}$ & Physical resource \\
\hline $\begin{array}{l}\text { T1C5 } \\
\text { T2C5 } \\
\text { T4C5 } \\
\text { T6C5 }\end{array}$ & $\begin{array}{l}\text { T1: Site superintendent } \\
\text { T2: Expeditor } \\
\text { T4: Tower crane operator } \\
\text { T6: Crane banksman }\end{array}$ & C5: Bad weather conditions & Physical environment \\
\hline $\mathrm{T} 2 \mathrm{C} 6$ & T2: Expeditor & $\begin{array}{l}\text { C6: Unavailable production and } \\
\text { transportation schedule }\end{array}$ & Informational schedule \\
\hline $\mathrm{T} 2 \mathrm{C} 7$ & T2: Expeditor & $\begin{array}{l}\text { C7: Lack of traceable status of prefabricated } \\
\text { products }\end{array}$ & Informational schedule \\
\hline $\mathrm{T} 2 \mathrm{C} 8$ & T2: Expeditor & $\begin{array}{l}\text { C8: Bad conditions of transportation } \\
\text { vehicle and route }\end{array}$ & Physical environment \\
\hline T3C9 & T3: Quality inspector & C9: Unavailable quality control hold-points & Physical prerequisite work \\
\hline $\begin{array}{l}\mathrm{T} 3 \mathrm{C} 10 \\
\mathrm{~T} 8 \mathrm{C} 10 \\
\end{array}$ & $\begin{array}{l}\text { T3: Quality inspector } \\
\text { T8: Prefabricated products Installer }\end{array}$ & $\begin{array}{l}\text { C10: Unavailable connection points for } \\
\text { handling }\end{array}$ & Physical prerequisite work \\
\hline T3C11 & T3: Quality inspector & C11: Lack of testing instructions & Informational quality \\
\hline $\begin{array}{l}\text { T4C12 } \\
\text { T6C12 } \\
\text { T7C12 }\end{array}$ & $\begin{array}{l}\text { T4: Tower crane operator } \\
\text { T6: Crane banksman } \\
\text { T7: Buffer foreman }\end{array}$ & $\begin{array}{l}\text { C12: Incomplete identification of } \\
\text { installation products }\end{array}$ & Physical prerequisite work \\
\hline $\begin{array}{l}\mathrm{T} 4 \mathrm{C} 13 \\
\mathrm{~T} 6 \mathrm{C} 13\end{array}$ & $\begin{array}{l}\text { T4: Tower crane operator } \\
\text { T6: Crane banksman }\end{array}$ & C13: Lack of lifting load capacity & Physical resource \\
\hline $\begin{array}{l}\mathrm{T} 4 \mathrm{C} 14 \\
\mathrm{~T} 6 \mathrm{C} 14 \\
\end{array}$ & $\begin{array}{l}\text { T4: Tower crane operator } \\
\text { T6: Crane banksman }\end{array}$ & C14: Lack of collision-free path planning & Informational safety \\
\hline $\begin{array}{l}\mathrm{T} 4 \mathrm{C} 15 \\
\mathrm{~T} 6 \mathrm{C} 15\end{array}$ & $\begin{array}{l}\text { T4: Tower crane operator } \\
\text { T6: Crane banksman }\end{array}$ & $\begin{array}{l}\text { C15: Unavailable lifting and placing } \\
\text { location in the assembly process }\end{array}$ & Informational schedule \\
\hline $\mathrm{T} 5 \mathrm{C} 16$ & T5: Tower foreman & $\begin{array}{l}\text { C16: Incomplete plan for the movement } \\
\text { and location of the crane }\end{array}$ & Informational schedule \\
\hline $\begin{array}{l}\text { T3C17 } \\
\text { T5C17 } \\
\text { T8C17 } \\
\text { T10C17 }\end{array}$ & $\begin{array}{l}\text { T3: Quality inspector } \\
\text { T5: Tower foreman } \\
\text { T8: Prefabricated products Installer } \\
\text { T10: Safety supervisor }\end{array}$ & C17: Unavailable equipment and devices & Physical resource \\
\hline T5C18 & T5: Tower foreman & C18: Lack of crane maintenance plan & Informational safety \\
\hline $\begin{array}{l}\text { T4C19 } \\
\text { T6C19 }\end{array}$ & $\begin{array}{l}\text { T4: Tower crane operator } \\
\text { T6: Crane banksman }\end{array}$ & $\begin{array}{l}\text { C19: Lack of blind zone operation } \\
\text { procedure/instruction }\end{array}$ & Informational schedule \\
\hline $\begin{array}{l}\text { T2C20 } \\
\text { T4C20 } \\
\text { T6C20 } \\
\text { T7C20 } \\
\text { T8C20 }\end{array}$ & $\begin{array}{l}\text { T2: Expeditor } \\
\text { T4: Tower crane operator } \\
\text { T6: Crane banksman } \\
\text { T7: Buffer foreman } \\
\text { T8: Prefabricated products Installer }\end{array}$ & $\begin{array}{l}\text { C20: Lack of visible and audible } \\
\text { communication mechanism }\end{array}$ & Informational schedule \\
\hline T7C21 & T7: Buffer foreman & C21: Inadequate buffer space & Physical resource \\
\hline T7C22 & T7: Buffer foreman & C22: Lack of optimal buffer layout & Informational schedule \\
\hline $\begin{array}{l}\mathrm{T} 4 \mathrm{C} 23 \\
\mathrm{~T} 6 \mathrm{C} 23 \\
\mathrm{~T} 7 \mathrm{C} 23\end{array}$ & $\begin{array}{l}\text { T4: Tower crane operator } \\
\text { T6: Crane banksman } \\
\text { T7: Buffer foreman }\end{array}$ & C23: Lack of optimal installation sequence & Informational schedule \\
\hline $\begin{array}{l}\mathrm{T} 2 \mathrm{C} 24 \\
\mathrm{~T} 3 \mathrm{C} 24 \\
\mathrm{~T} 4 \mathrm{C} 24 \\
\mathrm{~T} 6 \mathrm{C} 24 \\
\mathrm{~T} 7 \mathrm{C} 24 \\
\mathrm{~T} 8 \mathrm{C} 24\end{array}$ & $\begin{array}{l}\text { T2: Expeditor } \\
\text { T3: Quality inspector } \\
\text { T4: Tower crane operator } \\
\text { T6: Crane banksman } \\
\text { T7: Buffer foreman } \\
\text { T8: Prefabricated products Installer }\end{array}$ & C24: Unavailable prefabricated elements & Physical resource \\
\hline
\end{tabular}


Table 2. Cont.

\begin{tabular}{llll}
\hline ID & Trades & Constraints & Category \\
\hline T4C25 & T4: Tower crane operator & C25: Unavailable necessary rigging & Physical resource \\
T6C25 & T6: Crane banksman & & Physical resource \\
T7C25 & T7: Buffer foreman & C26: Inadequate workface/work space & Informational quality \\
\hline T8C26 & T8: Prefabricated products Installer & C27: Unavailable installation instructions & Physical resource \\
\hline T8C27 & T8: Prefabricated products Installer & C28: Unavailable temporary structures & Informational safety \\
\hline T8C28 & T8: Prefabricated products Installer & C29: Inadequate safety training and & hazards identification \\
T10C28 & T1: General laborer & C30: Unavailable safety check points & Physical prerequisite work \\
\hline T10C29 & T10: Safety supervisor & C31: Incomplete special personal protection & Informational safety \\
\hline T5C30 & T5: Tower foreman & equipment (PPE) instructions & \\
T10C30 & T10: Safety supervisor & & \\
\hline T10C31 & T10: Safety supervisor & & \\
\hline
\end{tabular}

\subsection{Determination of Constraint Links}

The second step determines links between the identified constraints. Links indicate the influences of one constraint over another, which can be defined in the tightness of collaboration, information sharing potential or communication in a network. A questionnaire survey (by email or face-to-face) was conducted with the interviewees from the 10 trades who had participated in the node identification. They were asked to decide whether a link exists between every two constraints and the direction of links. Then the interviewees were asked to quantify the identified links between two nodes in two aspects: (1) the intensity of impact and (2) the likeliness of this impact to happen. For example, one tower crane operator (T4) pointed out "the unavailable lift and place location in assembly process (C15) will be significantly affected by the availability of the collision-free path planning (C14). The intensity of impact is 5 (very important) and the likeliness of this impact to happen is $90 \%$ (highly possible)". Then the link (T4 C14 $\rightarrow \mathrm{T} 4 \mathrm{C} 15$ ) determined by this interviewee was 4.5 . After integrating all the questionnaires, the Delphi method was conducted to minimize bias from dominant participants. The influence level can be examined by multiplying the intensity of impact and the likeliness. The influent level is zero if no impact exists between two nodes.

\subsection{Visualization and Quantitation of the Critical Constraints and Interrelationships}

The third step is to achieve the visualization and quantitation, in order to examine the critical constraints and their interrelationships. SNA, a method to quantify the relations (links) between different elements (nodes) of a system by integrating mathematical applications [21], was used in this paper for network visualization and quantitation. NetMiner 4 [22], a software for conducting SNA, was selected in this paper. Compared with other methods (e.g., conventional regression analysis), SNA investigates the relationships within or among all the participants and reveals the overall network structure [23]. Six SNA indicators, including the network density and five node/link indicators (degree centrality, closeness centrality, node/link betweenness centrality, status centrality and eigenvector centrality) were selected to identify the critical trades associated constraints. The network density indicates the proportion of potential links in a network and it reflects the complexity of the overall system [21]. The concept of centrality is an outstanding criterion for evaluating the importance of node/link [24]. It determines the individual's roles within a network and highlights the most important actors of the network [25]. The degree, closeness and betweenness centrality have been widely advocated in SNA studies. Degree centrality is an indicator that counts the neighbors a node has, presenting the fundamental importance of nodes [26]. Closeness centrality reveals the capacity of a node to be reached, which is defined as the sum of the length of the shortest paths between the node and others [27]. Betweenness centrality is a measure of centrality in a graph based on shortest 
paths, showing the power of nodes [24]. In addition to the above mentioned three indicators, the status and eigenvector centrality were also used to show the comparisons. Status centrality estimates the prominence of nodes since it takes every connection between each node into account [22]. Eigenvector centrality is a more sophisticated method as it measures the influence of a node with different amounts of power [28]. Nodes with higher centrality are worth more attention. Corresponding strategies are then explored to mitigate the constraints for addressing the real-world schedule problems in PHP. The effectiveness of the strategies was further validated by professionals of whole processes of other PHPs in Hong Kong.

\section{SNA-Based Constraint Analyses}

\subsection{Results at the Network Level}

The links in the network are further defined to show the influence between two nodes. The network composes of 65 trade associated constraints connected by 659 links (Figure 3). In the network graph, nodes represent trades associated constraints and the node colors and shapes indicate the constraint types and trade categories, respectively. The arrows illustrate the influence of a constraint to another. Constraints with more links showing their central position compared with others. The network density is 0.158 and the average distance of nodes is 2.495 walks, indicating the network is dense enough [21].

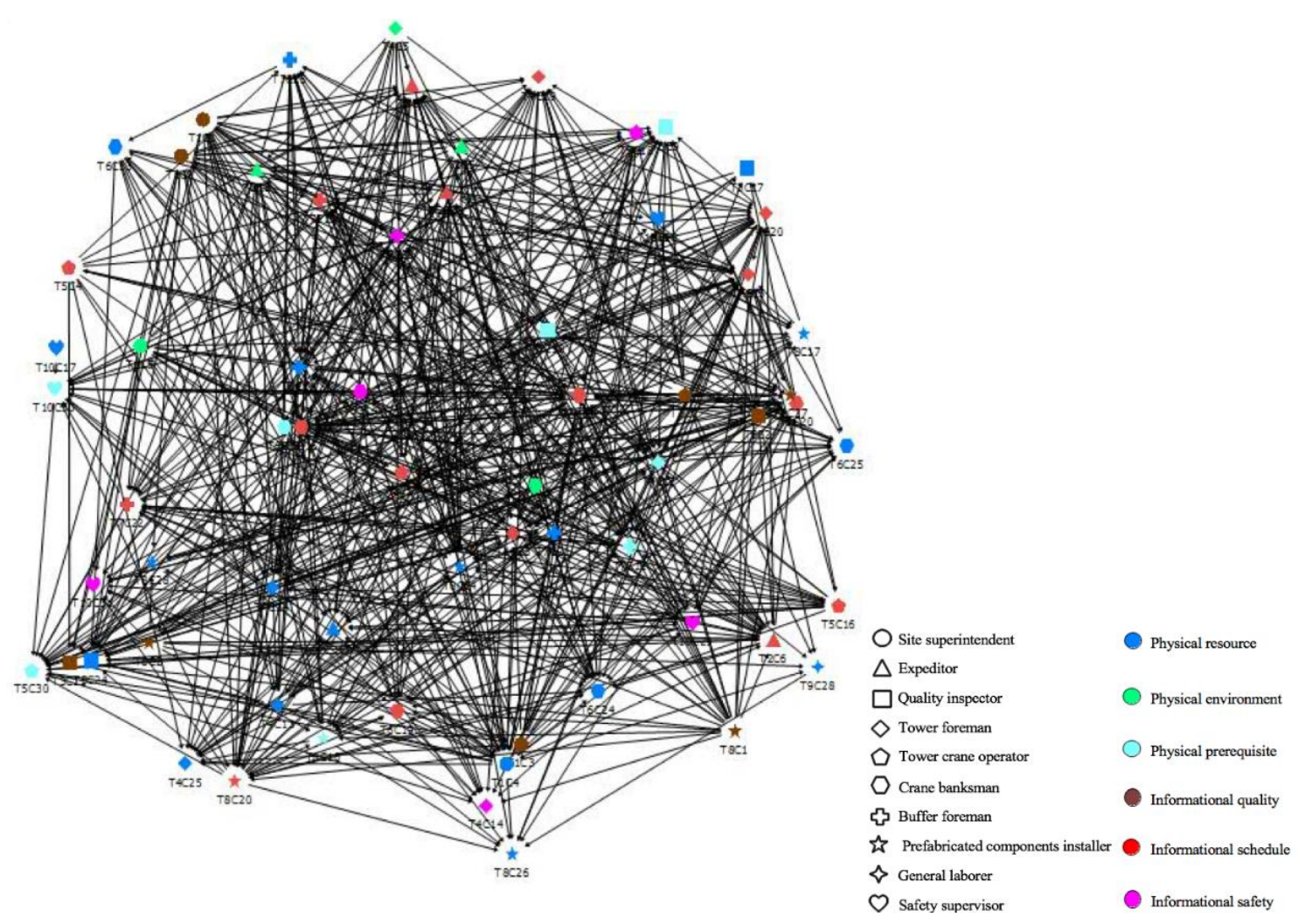

Figure 3. Trades associated schedule constraint network.

\subsection{Results at the Node Level}

The influences of nodes and their properties were explored by computing the node level indicators. The first fifteen rankings in each of the five indicators were presented in Table 3 and nodes ranked at the top three are highlighted in bold. The higher values of the indicators are worth more attention and they are considered as the critical constraints influencing the schedule. For example, "T1C4" ("Unavailable and unassigned labor resources" sourced from the site superintendent) has a higher 
out-degree centrality (0.8984) and out-status centrality (1.6879), indicating it exerts stronger influences on its neighbors and the entire network since both the direct and indirect influence via its immediate neighbors are calculated. "T1C4" also has the highest out-closeness centrality (0.5833), showing a higher degree to easily reach others (shortest distance). The importance of labor resources has also been demonstrated by several studies. For example, Blismas and Wakefield [17] pointed out that the leading driver of PHP is undoubtedly the increasing shortage of skilled labor, especially the machine-oriented skills labor. This is mainly caused by the fact that prefabrication is by nature different from in-situ cast concrete construction [29]. The unavailable and unassigned labor resources not only impact on the neighbored nodes (e.g., unavailable temporary structures for a general laborer (T9C28) but the entire network as skilled labors are needed for all the processes. Compared with the three indicators which show the influence of one node to other nodes, the node betweenness centrality evaluates the impact of one node to the connections. "T4C23" ("Lack of optimal installation sequence" sourced from the tower crane operator) has a higher node betweenness centrality compared with others (0.0921), showing its high occurrence to be an intermediary role to connect different parts of a network. According to Pryke [30], ignoring the nodes with high betweenness centrality may lead to disintegration. Compared with degree centrality, eigenvector centrality considered the different weight of high or low-scoring nodes. The eigenvector centrality of "T4C23" is also the highest $(0.2621)$, showing it is connected to many nodes which themselves have high scores. The importance of the optimal installation sequence has also been highlighted by Hwang, Shan [19] and Li, Hong [1]. For example, the lack of optimal installation sequence and the lack of collision-free path planning can lead to numerous reworks in the horizontal and vertical transportation of the prefabricated products. Similarly, another five essential constraints are also selected and addressed in this paper to better facilitate the schedule control of PHP, namely T6C23, T2C20, T4C15, T7C22 and T1C5 (See Table 3). Most of the constraints have also been highlights in previous studies, whereas the T4C15 ("Unavailable lift and place location in assembly process" sourced from the tower crane operator) has not been identified before. It determines how to locate the prefabricated products at points of lifting and placing in a fast manner.

A list of fifteen critical trade-associated relationships sourced from or targeted to the critical nodes is summarized in Table 4. Among the 659 links, 212 relationships source from or target to the identified constraints. A greater betweenness centrality means a more influencing tie connected with an interaction [30]. It presented that the relationship of "T4C15 $\rightarrow \mathrm{T} 6 \mathrm{C} 14$ " has the most influencing tie compared with others, followed by relations of "T7C23 $\rightarrow$ T7C22". The available lifting and placing location in the assembly process will directly influence the collision-free path planning for crane banksman. Without addressing this constraint, the probability of safety issues may happen. Although previous studies have not proposed this links before, it was highlighted by the interviewers. For the link "T7C23 $\rightarrow$ T7C22", the lack of optimal installation sequence may lead to the lack of optimal buffer layout. Without efficient arrangement of the prefabricated products at buffer, more rework and searching time is needed. Although most studies have demonstrated the vital role of the installation sequence for schedule control of PHP [19], few of them have explored its interaction with other constraints. 
Table 3. Top trade associated constraints based on the node-level results.

\begin{tabular}{|c|c|c|c|c|c|c|c|c|c|c|}
\hline Rank & Node & $\begin{array}{l}\text { Out-Degree } \\
\text { Centrality }\end{array}$ & Node & $\begin{array}{l}\text { Out-Status } \\
\text { Centrality }\end{array}$ & Node & $\begin{array}{l}\text { Node betweenness } \\
\text { Centrality }\end{array}$ & Node & $\begin{array}{l}\text { Out-Closeness } \\
\text { Centrality }\end{array}$ & Node & $\begin{array}{l}\text { Eigenvector } \\
\text { Centrality }\end{array}$ \\
\hline 1 & T1C4 & 0.8984 & T1C4 & 1.6879 & $\mathrm{~T} 4 \mathrm{C} 23$ & 0.0921 & T1C4 & 0.5833 & T4C23 & 0.2621 \\
\hline 2 & T6C23 & 0.7500 & T6C23 & 1.3250 & T1C4 & 0.0857 & T2C20 & 0.5234 & $\mathrm{~T} 6 \mathrm{C} 23$ & 0.2523 \\
\hline 3 & T4C23 & 0.6656 & T2C20 & 1.2452 & T4C15 & 0.0681 & T1C5 & 0.5026 & T4C15 & 0.2455 \\
\hline 4 & T2C20 & 0.6469 & T10C29 & 1.1973 & T10C30 & 0.0562 & T8C1 & 0.4977 & T7C22 & 0.2109 \\
\hline 5 & T8C20 & 0.6313 & T4C20 & 1.1589 & T2C20 & 0.0537 & T2C6 & 0.4851 & T7C23 & 0.1973 \\
\hline 6 & T4C20 & 0.6297 & T6C19 & 1.1428 & $\mathrm{~T} 2 \mathrm{C} 7$ & 0.0533 & $\mathrm{~T} 1 \mathrm{C} 1$ & 0.4851 & T8C24 & 0.1944 \\
\hline 7 & T7C20 & 0.6156 & $\mathrm{~T} 4 \mathrm{C} 23$ & 1.1304 & T4C19 & 0.0526 & $\mathrm{~T} 1 \mathrm{C} 2$ & 0.4804 & $\mathrm{~T} 7 \mathrm{C} 21$ & 0.1893 \\
\hline 8 & $\mathrm{~T} 6 \mathrm{C} 20$ & 0.5766 & T7C20 & 1.1238 & T10C29 & 0.0475 & T1C3 & 0.4804 & $\mathrm{~T} 1 \mathrm{C} 4$ & 0.1873 \\
\hline 9 & $\mathrm{~T} 2 \mathrm{C} 8$ & 0.5688 & T8C20 & 1.1141 & T6C23 & 0.0434 & T8C2 & 0.4757 & T7C24 & 0.1836 \\
\hline 10 & T10C29 & 0.5297 & T2C6 & 1.0822 & T7C12 & 0.0347 & $\mathrm{~T} 4 \mathrm{C} 20$ & 0.4667 & $\mathrm{~T} 4 \mathrm{C} 20$ & 0.1723 \\
\hline 11 & T7C22 & 0.5250 & T6C20 & 1.0721 & T8C10 & 0.0321 & T8C20 & 0.4667 & T6C15 & 0.1709 \\
\hline 12 & T6C19 & 0.4766 & T4C19 & 1.0448 & T8C20 & 0.0301 & $\mathrm{~T} 5 \mathrm{C} 2$ & 0.4657 & T7C12 & 0.1676 \\
\hline 13 & $\mathrm{~T} 2 \mathrm{C} 6$ & 0.4734 & $\mathrm{~T} 1 \mathrm{C} 5$ & 1.0079 & $\mathrm{~T} 3 \mathrm{C} 2$ & 0.0301 & T3C2 & 0.4623 & T7C20 & 0.1666 \\
\hline 14 & T8C27 & 0.4625 & T8C27 & 0.9522 & T7C22 & 0.0297 & T2C5 & 0.4615 & T6C20 & 0.1628 \\
\hline 15 & T4C19 & 0.4516 & T7C22 & 0.8939 & T3C10 & 0.0295 & T7C20 & 0.4579 & $\mathrm{~T} 2 \mathrm{C} 20$ & 0.1615 \\
\hline
\end{tabular}


Table 4. Critical interactions based on link betweenness centrality.

\begin{tabular}{|c|c|c|c|}
\hline Rank & Link ID & $\begin{array}{l}\text { Link betweenness } \\
\text { Centrality }\end{array}$ & Link Description \\
\hline 1 & $\mathrm{~T} 4 \mathrm{C} 15 \rightarrow \mathrm{T} 6 \mathrm{C} 14$ & 109.8 & $\begin{array}{l}\text { Unavailable lifting and placing location in the assembly } \\
\text { process for a tower crane operator leads to the lack of } \\
\text { collision-free path planning for a crane banksman }\end{array}$ \\
\hline 2 & $\mathrm{T7C} 23 \rightarrow \mathrm{T} 7 \mathrm{C} 22$ & 79.41 & $\begin{array}{l}\text { Lack of optimal installation sequence leads to the lack of } \\
\text { optimal buffer layout for a buffer foreman }\end{array}$ \\
\hline 3 & $\mathrm{~T} 2 \mathrm{C} 20 \rightarrow \mathrm{T} 2 \mathrm{C} 6$ & 65.92 & $\begin{array}{l}\text { Lack of visible and audible communication mechanism } \\
\text { leads to the unavailable production and transportation } \\
\text { schedule for an expeditor }\end{array}$ \\
\hline 4 & $\mathrm{~T} 2 \mathrm{C} 20 \rightarrow \mathrm{T} 6 \mathrm{C} 14$ & 47.71 & $\begin{array}{l}\text { Lack of visible and audible communication mechanism } \\
\text { for an expeditor leads to the lack of collision-free path } \\
\text { planning for a crane banksman }\end{array}$ \\
\hline 3 & $\mathrm{~T} 4 \mathrm{C} 13 \rightarrow \mathrm{T} 4 \mathrm{C} 23$ & 45.86 & $\begin{array}{l}\text { Lack of lifting load capacity leads to the lack of optimal } \\
\text { installation sequence for a tower crane operator }\end{array}$ \\
\hline 4 & $\mathrm{~T} 6 \mathrm{C} 13 \rightarrow \mathrm{T} 6 \mathrm{C} 23$ & 42.55 & $\begin{array}{l}\text { Lack of lifting load capacity leads to the lack of optimal } \\
\text { installation sequence for a crane banksman }\end{array}$ \\
\hline 5 & $\mathrm{~T} 1 \mathrm{C} 4 \rightarrow \mathrm{T} 8 \mathrm{C} 28$ & 36.13 & $\begin{array}{l}\text { Unavailable and unassigned labor resources for a site } \\
\text { superintendent leads to the unavailable temporary } \\
\text { structures for a prefabricated products installer }\end{array}$ \\
\hline 6 & $\mathrm{~T} 1 \mathrm{C} 4 \rightarrow \mathrm{T} 9 \mathrm{C} 28$ & 35.63 & $\begin{array}{l}\text { Unavailable and unassigned labor resources for a site } \\
\text { superintendent leads to the unavailable temporary } \\
\text { structures for a general laborer }\end{array}$ \\
\hline 7 & $\mathrm{~T} 1 \mathrm{C} 4 \rightarrow \mathrm{T} 10 \mathrm{C} 28$ & 35.63 & $\begin{array}{l}\text { Unavailable and unassigned labor resources for a site } \\
\text { superintendent leads to the unavailable temporary } \\
\text { structures for a safety supervisor }\end{array}$ \\
\hline 8 & $\mathrm{~T} 4 \mathrm{C} 23 \rightarrow \mathrm{T} 7 \mathrm{C} 21$ & 33.21 & $\begin{array}{l}\text { Lack of optimal installation sequence for a tower crane } \\
\text { operator leads to the inadequate buffer space for a buffer } \\
\text { foreman }\end{array}$ \\
\hline 9 & $\mathrm{~T} 7 \mathrm{C} 12 \rightarrow \mathrm{T} 6 \mathrm{C} 23$ & 30.07 & $\begin{array}{l}\text { Incomplete identification of installation products for a } \\
\text { buffer foreman leads to the lack of optimal installation } \\
\text { sequence for a crane banksman }\end{array}$ \\
\hline 10 & $\mathrm{~T} 1 \mathrm{C} 4 \rightarrow \mathrm{T} 5 \mathrm{C} 18$ & 27.4 & $\begin{array}{l}\text { Unavailable and unassigned labor resources for a site } \\
\text { superintendent leads to the lack of crane maintenance } \\
\text { plan and instruction for a tower foreman }\end{array}$ \\
\hline 11 & $\mathrm{~T} 2 \mathrm{C} 20 \rightarrow \mathrm{T} 5 \mathrm{C} 18$ & 26.06 & $\begin{array}{l}\text { Lack of visible and audible communication mechanism } \\
\text { for an expeditor leads to the lack of crane maintenance } \\
\text { plan and instruction for a tower foreman }\end{array}$ \\
\hline 12 & $\mathrm{~T} 7 \mathrm{C} 12 \rightarrow \mathrm{T} 4 \mathrm{C} 23$ & 21.96 & $\begin{array}{l}\text { Incomplete identification of installation items for a } \\
\text { buffer foreman leads to the lack of optimal installation } \\
\text { sequence for a tower crane operator }\end{array}$ \\
\hline 13 & $\mathrm{~T} 4 \mathrm{C} 25 \rightarrow \mathrm{T} 4 \mathrm{C} 15$ & 21.25 & $\begin{array}{l}\text { Unavailable necessary rigging leads to the unavailable } \\
\text { lifting and placing location in the assembly process for a } \\
\text { tower crane operator }\end{array}$ \\
\hline 14 & $\mathrm{~T} 6 \mathrm{C} 12 \rightarrow \mathrm{T} 6 \mathrm{C} 23$ & 21.13 & $\begin{array}{l}\text { Incomplete identification of installation items for leads } \\
\text { to the Lack of optimal installation sequence for a crane } \\
\text { banksman }\end{array}$ \\
\hline 15 & $\mathrm{~T} 4 \mathrm{C} 12 \rightarrow \mathrm{T} 4 \mathrm{C} 23$ & 20.36 & $\begin{array}{l}\text { Incomplete identification of installation items leads to } \\
\text { lack of optimal installation sequence for a tower crane } \\
\text { operator }\end{array}$ \\
\hline
\end{tabular}

\section{Discussion}

\subsection{Identification of Critical Challenges within the Assembly Process of PHP}

Based on the results, the significant challenges were identified by categorizing the constraints and their relationships (Table 5). For example, four relationships (including "T4C13 $\rightarrow$ T4C23", $\mathrm{T} 7 \mathrm{C} 12 \rightarrow \mathrm{T} 4 \mathrm{C} 23, \mathrm{~T} 4 \mathrm{C} 12 \rightarrow \mathrm{T} 4 \mathrm{C} 23$ and "T4C23 $\rightarrow \mathrm{T} 7 \mathrm{C} 21$ ") described issues about the lack of optimal installation sequence. "T4C15 $\rightarrow \mathrm{T} 6 \mathrm{C} 14$ " and "T4C25 $\rightarrow \mathrm{T} 4 \mathrm{C} 15$ " revealed the drivers of unavailable lifting and placing location in the assembly process. "T7C23 $\rightarrow$ T7C22" shed lights on the lack of optimal buffer layout may influence the schedule of PHP. These three links were put under one category in 
which major challenges in the schedule of PHP were determined: "Lack of optimal location planning". Following the same principle, three significant challenges are determined: (1) Communication barriers among different trades; (2) Lack of optimal installation planning; and (3) Unavailable labor and equipment resources.

Table 5. Critical trades-associated constraints.

\begin{tabular}{|c|c|c|c|c|}
\hline $\begin{array}{l}\text { Challenges in the } \\
\text { Schedule of PHP }\end{array}$ & $\begin{array}{l}\text { Critical Constraint } \\
\text { Code }\end{array}$ & Constraints & Trade & $\begin{array}{l}\text { Associated } \\
\text { Critical Links }\end{array}$ \\
\hline $\begin{array}{l}\text { 1. Communication } \\
\text { barriers among } \\
\text { different trades }\end{array}$ & $\mathrm{T} 2 \mathrm{C} 20$ & $\begin{array}{l}\text { Lack of visible and audible } \\
\text { communication } \\
\text { mechanism }\end{array}$ & Expeditor & $\begin{array}{l}\text { T2C20 } \rightarrow \text { T2C6 } \\
\text { T2C20 } \rightarrow \text { T8C17 } \\
\text { T2C20 } \rightarrow \text { T5C } 18\end{array}$ \\
\hline \multirow[t]{3}{*}{$\begin{array}{l}\text { 2. Lack of optimal } \\
\text { installation } \\
\text { planning }\end{array}$} & $\mathrm{T} 4 \mathrm{C} 15$ & $\begin{array}{l}\text { Unavailable lifting and } \\
\text { placing location in the } \\
\text { assembly process }\end{array}$ & $\begin{array}{l}\text { Tower crane } \\
\text { operator }\end{array}$ & $\begin{array}{l}\text { T4C15 } \rightarrow \text { T6C14 } \\
\mathrm{T} 4 \mathrm{C} 25 \rightarrow \mathrm{T} 4 \mathrm{C} 15\end{array}$ \\
\hline & $\mathrm{T} 4 \mathrm{C} 23$ & $\begin{array}{l}\text { Lack of optimal } \\
\text { installation sequence }\end{array}$ & $\begin{array}{l}\text { Tower crane } \\
\text { operator }\end{array}$ & $\begin{array}{l}\mathrm{T} 4 \mathrm{C} 13 \rightarrow \mathbf{T} 4 \mathrm{C} 23 \\
\mathrm{~T} 7 \mathrm{C} 12 \rightarrow \mathbf{T} 4 \mathrm{C} 23 \\
\mathrm{~T} 4 \mathrm{C} 12 \rightarrow \mathbf{T} 4 \mathrm{C} 23 \\
\mathbf{T} 4 \mathrm{C} 23 \rightarrow \mathrm{T} 7 \mathrm{C} 21\end{array}$ \\
\hline & $\mathrm{T} 6 \mathrm{C} 23$ & $\begin{array}{l}\text { Lack of optimal } \\
\text { installation sequence }\end{array}$ & Crane banksman & $\begin{array}{l}\mathrm{T} 6 \mathrm{C} 13 \rightarrow \mathbf{T} 6 \mathrm{C} 23 \\
\mathrm{~T} 7 \mathrm{C} 12 \rightarrow \mathbf{T} 6 \mathrm{C} 23 \\
\mathrm{~T} 6 \mathrm{C} 12 \rightarrow \mathbf{T} 6 \mathrm{C} 23\end{array}$ \\
\hline \multirow[t]{2}{*}{$\begin{array}{l}\text { 3. Unavailable } \\
\text { labor and space } \\
\text { resources }\end{array}$} & $\mathrm{T} 1 \mathrm{C} 4$ & $\begin{array}{l}\text { Unavailable and } \\
\text { unassigned labor resources }\end{array}$ & Site superintendent & $\begin{array}{l}\text { T1C4 } \rightarrow \text { T8C28 } \\
\text { T1C4 } \rightarrow \text { T9C28 } \\
\text { T1C4 } \rightarrow \text { T10C28 } \\
\text { T1C4 } \rightarrow \text { T5C18 }\end{array}$ \\
\hline & T7C22 & $\begin{array}{l}\text { Lack of optimal buffer } \\
\text { layout }\end{array}$ & Buffer foreman & $\mathrm{T7C23} \rightarrow \mathrm{T} 7 \mathrm{C} 22$ \\
\hline
\end{tabular}

The communication barriers have long been highlighted by previous studies when conducting the PHP $[1,31]$. The frequent communication and effective coordination can ensure the logistics arrive on time and reduce the number of defects during the assembly process. Li, Shen [7] and $\mathrm{Li}, \mathrm{Wu}$ [32] pointed out that advanced technologies (e.g., BIM and smart construction objects (SCOs)) can better enhance the information communication and real-time tracking of PHP, which helps to control schedule. Similar studies have been conducted by Isaac, Curreli [33] and Niu, Lu [34]. Mostafa, Kim [35] also emphasized that BIM can effectively minimize the communication-specific issues for prefabrication practice. If the lack of installation planning cannot be timely addressed, they will prevent the crane efficiency from transporting the prefabricated products (from lift point to the place point) in a JIT manner. The labor and equipment resource limitations also lead to a resource-constrained project scheduling problem [11]. It shows the demand for retraining the labors both on-site and off-site and the need to shift the labor-intensive construction industry to a knowledge-based industry.

The identified constraints were further validated by 14 professionals of whole processes of PHP in Hong Kong (See the background of the interviewees and their comments in Appendix A). All industry professionals had more than 10 years of experience in the development, operation and management of PHP projects and related technologies. It is expected that they can provide an unbiased assessment.

\subsection{SWP-Enabled Strategies for Automatic Constraint Modeling of PHP}

The identified trade-associated constraints and their relationships shown the key points for schedule control of PHP. However, this identification process is relative static and can be executed once, whereas the statuses of constraints change over time. How to achieve automatic constraints identification and dynamic constraint relationship mapping under different constraint scenarios is thus vital for better constraint management. Since the latest constraint information is essential for the superintendent to check progress and to improve constraints timely. Therefore, a smart work 
packaging (SWP) system based on the established work packaging and smart construction objects (SCOs) is suggested in this paper. SWP can be defined as the PHP workflows (e.g., technical process) decomposed in accordance with production breakdown structure (PBS) of building systems that are made smart by augmenting with the capacities of visualizing, tracking, sensing, processing, networking, reasoning so that they can be executed autonomously. An example of SWP-enabled system for achieving better constraint modelling is illustrated in the following:

- An SWP within prefabricated products related functional and physical information, generated from BIM platform based on the building systems and PBS of PHP, is assigned to a site buffer operator for managing related constraints so that efficient on-site assembly process and Just-in-time prefabricated products delivery can be achieved. When the first batch of prefabricated products arrived, the SWP starts to assist site buffer operator in executing constraint management. The SNA module will be embedded as a sub-service to identify the critical constraints such as the availability of workforce and work face in the assembly position point, the quality of arrived prefabricated products, the availability of space and workforce in site buffer and their interrelationships such as composition, interface and dependency. Workers from buffer operator will register and log-in through SNA sub-service of their own SWP and abstract constraint template. The constraint relationships will then be scored and evaluated. When the critical constraints (e.g., space constraint in the buffer limits the stockpiles of prefabricated products) have been identified, the SWP can assign a task to the buffer foreman with optimal solutions. For example, the autonomous crane tower near the buffer can pick up the task to transport the prefabricated products from trailer to the buffer in an optimal path (e.g., safety, short duration).

To realize scenarios as the one given, two steps are designed for SNA sub-service module: First, automatic constraint identification which requires agilely detecting all critical constraints is conducted. The SWP can enhance this step in a passive autonomy manner by pre-programming the templated constraint classification with an open-data integration approach for constraint instantiation. Although PHP projects are unique, they share some similar types of constraints at the operational level and this observation motivated SWP to develop a templated database for organizing the potentially significant amount of constraints. Once the template is applied to the SWP, it instantiates a set of pre-defined constraints and networking each constraint in this SWP or among other SWPs to identify critical constraints in the near future tasks. Second, dynamic constraint relationship mapping is conducted. In real PHP project situation, constraints are not independent and have dynamic interrelationships. SWP can embed the constraint awareness into the physical environment and informational process to sense and simulate the interrelationships by push or pull interaction modes.

\section{Conclusions}

This paper examined the critical trade associated constraints and modeled their interrelationships in task executions during the on-site assembly process of PHP. Six indicators of SNA method, namely network density, degree centrality, closeness centrality, betweenness centrality, status centrality and eigenvector centrality were calculated using the NetMiner 4 software. Three SWP-enabled strategies were suggested to address the challenges within the schedule control of PHP.

The paper concludes that seven critical trade-associated constraints are worth higher attention for schedule control of PHP. These constraints were further analysed and it indicated that the on-site team should focus more attention on the availability of the labor resources, the optimal installation planning and the effectiveness of the communication mechanism. Retraining the labors becomes quite urgent as the increasing shortage of machine-oriented skills labor. The on-site team members (especially the crane banksman and tower crane operator) should pay more attention to the optimal installation sequence and collision-free path planning, which can dramatically reduce the reworks in the horizontal and vertical transportation of the prefabricated products. Advanced technologies were also encouraged (e.g., RFID chips, BIM interface, GPS) to enhance the frequent communication 
and effective coordination among different trades. The paper contributes theoretically to identify a complete boundary of trades associated constraints and their relationships existing in and among PHP from a network perspective. The findings are also expected to benefit practitioners on what significant challenges exist in the schedule management and proposes a new perspective of using SWP-enabled strategies to mitigate schedule problems.

Although the constraint identification process by using SNA is static, it is the first and essential step to conduct a smarter constraint management of PHP. To explore automated constraint identification and dynamic constraint relationship mapping under different constraint scenarios, the SWP-enabled strategies were put forward in this paper. An example for achieving better constraint modelling was provided for better illustrating the proposed strategies. Two steps of the SNA sub-service module were also suggested. The exploration of the SWP-enabled strategies helps to better facilitate the use of SNA technique to identify the critical constraints and their dynamic relationships automatically considering different scenarios and more resilient process.

Though the limited single case was adopted in this paper, the challenges proposed can still show practical insights into prefabricated buildings in Hong Kong. Future empirical studies could be undertaken to compare the findings and to develop more strategies through multi-case study approach. Additionally, further studies should be explored to achieve the dynamically, timely and efficiently improvement and continual prediction of the constraints after identification process. Therefore, constraint optimization and monitoring are suggested. For example, advanced optimization algorithms can be conducted for efficient layout design considering both optimal buffer utilization and hoisting sequencing (e.g., first-in-first-assembly). Different action strategies according to the checking results can be performed and the historical variation can be used to train and predict the next variation in a robustness manner.

Author Contributions: Conceptualization, P.G. and X.L.; methodology, P.G. and Y.T.; software, Y.T.; validation, X.L. and L.L.; formal analysis, Y.T.; investigation, P.G.; resources, P.G. and X.L.; data curation X.L. and L.L.; writing-original draft preparation, P.G.; writing-review and editing, P.G., Y.T. and X.L.; visualization, P.G.; supervision, P.G.; project administration, P.G.

Funding: This research received no external funding.

Conflicts of Interest: The authors declare no conflict of interest. 


\section{Appendix A. The Background of the 14 Interviewees and Their Contributions}

\begin{tabular}{llll}
\hline No. Organization & Expertise & Years of Experience
\end{tabular}

Comments

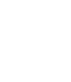

2

Supply Chain Management

$20+$

Lean Construction

$20+$
$20+$

1. The typhoon and extremely hot weather in Hong Kong influence the assembly process.

2. On-site assembly process needs more skilled workers.

3. The lifting load capacity should be satisfied before the start of PHP

1. Communicating with logistics efficiently ensures the JIT delivery of products, which is very important for schedule control.

2. Traceability of prefabricated products reduce the uncertainty. The RFID chips are useful.

3. The site superintendent needs to make cycle plan to control the whole schedule.

1. To achieve the JIT delivery is important for PHP compared with traditional construction.

2. There should be completed plans for the assembly cycle, location of crane, the placing location of the products, the procedure for installation, the collision-free path, etc. The unvalued steps should be recognized to reduce the waiting time.

1. How to identify the critical constraints automatically using SWP is important. The templated constraints classification through integrating the open-data should be established initially.

2. For example, When the prefabricated products arrived at the construction site, SWP starts to identify the constraints, e.g., the availability of workforce in the assembly location, the quality of arrived prefabricated products, the availability of space and workforce in site and their interrelationships by networking with other SWPs. 


\section{No. Organization}

Gammon Construction

(Contractor)

6

BIM

Construction Management

$15+$

$10+$

7

Construction Management

$15+$

Aggressive (Contractor)

BIM

$10+$
Comments

1. Labor and equipment resource limitations should be further addressed. More skilled workers are needed.

2. The optimal buffer layout reduces the searching time during the assembly process.

3. The installation sequence instruction reduces the non-value time to achieve the schedule control.

1. Completed BIM model improves the constructability of PHP and reduces the rework.

2. More advance technologies are encouraged.

3. The whole assembly process of PHP should be more automatic, integrated, intelligent and traceable.

4. How to address the current communication barriers is vital, especially during the delivery and lifting process.

1. Communication mechanism needs to be enhanced.

2. Delivering products on time reduces the waiting time and helps to control schedule.

3. Optimal installation planning reduces the reworks in the horizontal and vertical transportation of the prefabricated products.

1. The SWP system can automatically simulate and to analyse the effect on project performance under different constraints scenarios.

2. For example, the SWP can be assigned to a site buffer foreman for managing related constraints so that efficient on-site assembly process and JIT prefabricated products delivery can be achieve. 


\begin{tabular}{llll}
\hline No. Organization & Expertise & Years of Experience & Comments
\end{tabular}

$10+$

WHS (Manufacturer)

Logistics and Positioning Technologies
1. The Production Breakdown System (PBS) can be established based on the system of prefabrication.

2. Skilled labors are needed.

3. Effective communication between different stakeholders helps to reduce the misunderstanding.

1. How to optimize the constraints is a succeeding functional strategy of constraints identification, which ensures all the constraints to be timely improved. The detailed timeline with alternative network paths should be pre-planned.

2. For example, when the space constraint in the buffer limits the stockpiles of prefabricated product, the SWP can assign a task to the buffer foreman with optimal solutions. Then crane tower near the buffer can pick up the task to transport the prefabricated products from trailer to the buffer in an optimal path.

1. Technique (e.g., GPS) for recording the traceable status of prefabricated products can help to reduce the uncertainty of deliveries.

2. The JIT delivery relies heavily on the instruction of on-site work team and the availability of the prefabricated elements.

3. The height and weight limit on the road for the vehicle, the traffic congestion, the condiction of the vehicle, the quantities of the prefabricated elements all have influences on the delivery time.

1. To achieve constraints traceability is important. For example, the RFID and IOT system can be used for indetification purposes. When project suffers delay, the real-time status of constraints can also be used as references for decision-making.

2. The status should be updated timely to better facilitate decision making. 


\begin{tabular}{|c|c|c|c|c|}
\hline No. & Organization & Expertise & Years of Experience & Comments \\
\hline 13 & CIC (Consultancy) & Lean Construction & $20+$ & $\begin{array}{l}\text { 1. Retraining labors is important and } \mathrm{CIC} \text { has been conducting a number } \\
\text { of part-time training courses for meeting special requests from } \\
\text { the construction. }\end{array}$ \\
\hline \multirow[t]{2}{*}{14} & \multirow{2}{*}{ TSL (IT Consultancy) } & \multirow{2}{*}{ IoTs Solutions } & \multirow[t]{2}{*}{$15+$} & $\begin{array}{l}\text { 1. To continually track, update and predict the status of the critical } \\
\text { constraints enable more resilience to the surroundings. }\end{array}$ \\
\hline & & & & $\begin{array}{l}\text { 2. Apart from the constraint identification process, constraints under } \\
\text { different scenarios should also be studied. }\end{array}$ \\
\hline
\end{tabular}




\section{References}

1. Li, C.Z.; Hong, J.; Xue, F.; Shen, G.Q.; Xu, X.; Mok, M.K. Schedule risks in prefabrication housing production in Hong Kong: A social network analysis. J. Clean. Prod. 2016, 134, 482-494. [CrossRef]

2. Jaillon, L.; Poon, C.-S. Sustainable construction aspects of using prefabrication in dense urban environment: A Hong Kong case study. Constr. Manag. Econ. 2008, 26, 953-966. [CrossRef]

3. Lu, W.; Yuan, H. Investigating waste reduction potential in the upstream processes of offshore prefabrication construction. Renew. Sustain. Energy Rev. 2013, 28, 804-811. [CrossRef]

4. Tam, V.W.; Tam, C.M.; Zeng, S.X.; Ng, W.C. Towards adoption of prefabrication in construction. Build. Environ. 2007, 42, 3642-3654. [CrossRef]

5. Li, C.Z.; Xu, X.; Shen, G.Q.; Fan, C.; Li, X.; Hong, J. A model for simulating schedule risks in prefabrication housing production: A case study of six-day cycle assembly activities in Hong Kong. J. Clean. Prod. 2018, 185, 366-381. [CrossRef]

6. Goulding, J.S.; Pour Rahimian, F.; Arif, M.; Sharp, M. New offsite production and business models in construction: Priorities for the future research agenda. Arch. Eng. Des. Manag. 2015, 11, 163-184. [CrossRef]

7. Li, C.Z.; Shen, G.Q.; Xu, X.; Xue, F.; Sommer, L.; Luo, L. Schedule risk modeling in prefabrication housing production. J. Clean. Prod. 2017, 153, 692-706. [CrossRef]

8. Zhong, R.Y.; Peng, Y.; Xue, F.; Fang, J.; Zou, W.; Luo, H.; Ng, S.T.; Lu, W.; Shen, G.Q.; Huang, G.Q. Prefabricated construction enabled by the Internet-of-Things. Autom. Constr. 2017, 76, 59-70. [CrossRef]

9. Li, X.; Shen, G.Q.; Wu, P.; Yue, T. Integrating Building Information Modeling and Prefabrication Housing Production. Autom. Constr. 2019, 100, 46-60. [CrossRef]

10. Li, C.Z.; Xue, F.; Li, X.; Hong, J.; Shen, G.Q. An Internet of Things-enabled BIM platform for on-site assembly services in prefabricated construction. Autom. Constr. 2018, 89, 146-161. [CrossRef]

11. Liu, H.; Al-Hussein, M.; Lu, M. BIM-based integrated approach for detailed construction scheduling under resource constraints. Autom. Constr. 2015, 53, 29-43. [CrossRef]

12. Blackmon, T.; Saxena, R.; Song, L. A conceptual framework for total constraint management in construction. In Proceedings of the 28th International Symposium on Automation and Robotics in Construction, Seoul, Korea, 29 June-2 July 2011; pp. 419-424. [CrossRef]

13. Blismas, N.G.; Pendlebury, M.; Gibb, A.; Pasquire, C. Constraints to the use of off-site production on construction projects. Archit. Eng. Des. Manag. 2005, 1, 153-162. [CrossRef]

14. Gibb, A.; Isack, F. Re-engineering through pre-assembly: Client expectations and drivers. Build. Res. Inf. 2003, 31, 146-160. [CrossRef]

15. Zhang, W.; Lee, M.W.; Jaillon, L.; Poon, C.-S. The hindrance to using prefabrication in Hong Kong's building industry. J. Clean. Prod. 2018, 204, 70-81. [CrossRef]

16. Leu, S.-S.; Hwang, S.-T. Optimal repetitive scheduling model with shareable resource constraint. J. Constr. Eng. Manag. 2001, 127, 270-280. [CrossRef]

17. Blismas, N.; Wakefield, R. Drivers, constraints and the future of offsite manufacture in Australia. Constr. Innov. 2009, 9, 72-83. [CrossRef]

18. Gan, X.; Chang, R.; Wen, T. Overcoming barriers to off-site construction through engaging stakeholders: A two-mode social network analysis. J. Clean. Prod. 2018, 201, 735-747. [CrossRef]

19. Hwang, B.-G.; Shan, M.; Looi, K.-Y. Key constraints and mitigation strategies for prefabricated prefinished volumetric construction. J. Clean. Prod. 2018, 183, 183-193. [CrossRef]

20. Arashpour, M.; Wakefield, R.; Abbasi, B.; Lee, E.; Minas, J. Off-site construction optimization: Sequencing multiple job classes with time constraints. Autom. Constr. 2016, 71, 262-270. [CrossRef]

21. Wasserman, S.; Faust, K. Social Network Analysis: Methods and Applications; Cambridge University Press: Cambridge, UK, 1994; Volume 8.

22. Cyram, N. Cyram Netminer 4.1; Cyram: Seoul, Korea, 2013.

23. Dogan, S.Z.; Arditi, D.; Gunhan, S.; Erbasaranoglu, B. Assessing coordination performance based on centrality in an e-mail communication network. J. Manag. Eng. 2013, 31, 04014047. [CrossRef]

24. Freeman, L.C. Centrality in social networks conceptual clarification. Soc. Netw. 1978, 1, 215-239. [CrossRef]

25. Durland, M.M.; Fredericks, K.A. An introduction to social network analysis. New Dir. Eval. 2005, 2005, 5-13. [CrossRef] 
26. Lienert, J.; Schnetzer, F.; Ingold, K. Stakeholder analysis combined with social network analysis provides fine-grained insights into water infrastructure planning processes. J. Environ. Manag. 2013, 125, 134-148. [CrossRef] [PubMed]

27. Borgatti, S.P. Centrality and AIDS. Connections 1995, 18, 112-114.

28. Gould, P.R. On the geographical interpretation of eigenvalues. Trans. Inst. Br. Geogr. 1967, 53-86. [CrossRef]

29. Chiang, Y.-H.; Chan, E.H.-W.; Lok, L.K.-L. Prefabrication and barriers to entry-A case study of public housing and institutional buildings in Hong Kong. Habitat Int. 2006, 30, 482-499. [CrossRef]

30. Pryke, S. Social Network Analysis in Construction; John Wiley \& Sons: Hoboken, NJ, USA, 2012.

31. Nawi, M.; Lee, A.; Nor, K. Barriers to implementation of the industrialised building system (IBS) in Malaysia. Built Hum. Environ. Rev. 2011, 4, 34-37.

32. Li, X.; Wu, P.; Shen, G.Q.; Wang, X.; Teng, Y. Mapping the knowledge domains of Building Information Modeling (BIM): A bibliometric approach. Autom. Constr. 2017, 84, 195-206. [CrossRef]

33. Isaac, S.; Curreli, M.; Stoliar, Y. Work packaging with BIM. Autom. Constr. 2017, 83, 121-133. [CrossRef]

34. Niu, Y.; Lu, W.; Liu, D.; Chen, K.; Anumba, C.; Huang, G.G. An SCO-Enabled Logistics and Supply Chain-Management System in Construction. J. Constr. Eng. Manag. 2016, 143, 04016103. [CrossRef]

35. Mostafa, S.; Kim, K.P.; Tam, V.W.; Rahnamayiezekavat, P. Exploring the status, benefits, barriers and opportunities of using BIM for advancing prefabrication practice. Int. J. Constr. Manag. 2018, 1-11. [CrossRef]

(C) 2019 by the authors. Licensee MDPI, Basel, Switzerland. This article is an open access article distributed under the terms and conditions of the Creative Commons Attribution (CC BY) license (http://creativecommons.org/licenses/by/4.0/). 